\title{
Effect of Alumina Amount on the Bioactivity of Dense Magnesium Fluorapatite/Alumina Composite in Simulated Body Fluid (SBF) using Taguchi Method
}

Hejazi MS ${ }^{1,2^{\star}}$, Meratian $\mathbf{M}^{1}$, Ahmadian $\mathbf{M}^{1,2}$ and Fathi $\mathbf{M H}^{1,3}$

${ }^{1}$ Department of Materials Engineering, Isfahan University of Technology, Isfahan, 84156-83111, Iran

${ }^{2}$ Biomaterials Research Group, Department of Materials Engineering, Isfahan University of Technology, Isfahan, 8415683111, Iran

${ }^{3}$ Dental Materials Research Center, Isfahan University of Medical Sciences, Isfahan, Iran

\begin{abstract}
Bioactivity of magnesium fluorapatite is basically affected by the amount of dissolved $\beta$-TCP in Simulated Body Fluid (SBF). It was the purpose of the current work to prepare and characterize magnesium fluorapatite with different amounts of alumina, and to investigate the effect of alumina amount on magnesium fluorapatite (MFA) bioactivity and mechanical properties. Magnesium fluorapatite/alumina composite bulk samples with different amounts of alumina were synthesized via mechanochemical activation (by high-energy ball milling process) followed by two-step sintering processes using Taguchi method and analysis of variance (ANOVA). While, variable parameters include: initial temperature $\left(\mathrm{T}_{1}\right)$, second temperature $\left(\mathrm{T}_{2}\right)$ and dwell time $\left(\mathrm{t}_{2}\right)$. In vitro bioactivity evaluation was performed by soaking the prepared samples in Simulated Body Fluid (SBF) for predicted period of times. In order to characterize the samples, identify the formed bone like-apatite, and determine the concentration amount of released ions in the SBF, X-ray diffraction, Fourier transform infrared spectrometry, scanning electron microscopy, inductively-coupled plasma, and spectrometry techniques were utilized. The results indicated that the MFA/alumina composites with various amounts of alumina showed more bioactivity in SBF due to higher dissolution of $\beta$-TCP.
\end{abstract}

Keywords: Magnesium-fluorapatite; Bio composite; Bioactivity; Simulated body fluid; Two-step sintering; Taguchi method

\section{Introduction}

The use of Hydroxyapatite (HA) as an implant for bone replacement in restorative dental and orthopedic applications owes much to the similarity of its chemical composition and crystallographic structure to those of the bone mineral part; HA, however, suffers from poor mechanical properties $[1,2]$. It is possible to obtain improved mechanical properties such as strength, wear resistance, fracture toughness and hardness by combining HA with hard alumina [3-5]. In order to implant HA prostheses in the human body, it is essential to create bonding to a live bone similar to the apatite formed in a Simulated Body Fluid (SBF) [6,7]. The in vivo formation of apatite on bioactive ceramics can be reproduced by an acellular simulated body fluid (SBF) with ion concentrations nearly equal to those in the blood plasma [8]. The biologically active bone-like calcium-phosphate (CaP) layer is necessarily formed on the implant surface [9]. It is accepted that HA and $\beta$-TCP form chemical bonds directly with bone tissues without the intervention of soft tissues [10]. A number of studies have been conducted on the bioactivity of ceramic composites with alumina and/or HA. Zhang et al. [11] showed that $\mathrm{Al}_{2} \mathrm{O}_{3} /$ diopside ceramic composites had both good mechanical properties and good biological activity. Priya et al. [12] observed that calcium phosphate-mullite composites were capable of producing a porous apatite layer in vitro. Xin et al. [13] investigated the apatite layer formation and found that it occurred on the surface of HA/316L SS biocomposites. Taguchi's approach is a method for improving the quality of a product through minimizing the effect of variation without eliminating the causes [14]. A typical two-step sintering schedule consists of a first heating step to an initial temperature $\left(T_{1}\right)$ for short time $\left(t_{1}\right)$ and, on a second step, the immediate cooling down to a lower temperature $\left(\mathrm{T}_{2}\right)$ for a relatively long time $\left(t_{2}\right)$ [15]. The method was tested in a variety of materials, including alumina [16], alumina- zirconia [17] and hydroxyapatite [18]. ANOVA could be estimated the appropriate orthogonal array for experiments [19]. In the present work, the bioactivity, fracture toughness and hardness of MFA samples with various amounts of alumina $(0,10,25$, and $50 \mathrm{wt} \%)$ under a two-step sintering processes using Taguchi method in SBF is studied.

\section{Materials and Methods}

MFA/alumina composites were synthesized using ball milling. In order to obtain MFA powders, phosphorous pentoxide $\left(\mathrm{P}_{2} \mathrm{O}_{5}\right)$, calcium hydroxide $\left(\mathrm{Ca}(\mathrm{OH})_{2}\right)$, magnesium hydroxide $\left(\mathrm{Mg}(\mathrm{OH})_{2}\right)$, and calcium fluoride $\left(\mathrm{CaF}_{2}\right)$ powders (all p.a, Merck) were mechanochemically activated using a high-energy planetary ball mill (Fretch Pulverisette-5, Germany) at ambient temperature for 12 hours. In order to obtain MFA/alumina composites with 10,25 and $50 \mathrm{wt} \%$ alumina, $\alpha-\mathrm{Al}_{2} \mathrm{O}_{3}$ (Aldrich, USA) was added to MFA and milled for 3 hours. A tensioncompression of manufacturer device under a pressure of $300 \mathrm{MPa}$ was used for the preparation of green pellets. Two-step sintering processes were designed and applied by Taguchi method for composites. In the Taguchi parameter design, three initial temperatures $(1150,1200$ and $\left.1250^{\circ} \mathrm{C}\right)$, three secondary temperature $\left(1000,1100\right.$ and $\left.1150^{\circ} \mathrm{C}\right)$ and three dwell times $(4,8$ and 12 hours) were selected. The bulk samples were evaluated with respect to their bioactivity using an SBF immersion test with features of the blood serum (i.e., $\mathrm{pH}=7.4$ at $37^{\circ} \mathrm{C}$ ) [7]. The bulked samples were immersed in SBF with different test characteristics.

*Corresponding author: Hejazi MS, Department of Materials Engineering Isfahan University of Technology, Isfahan, 84156-83111, Iran, Tel: 983-113-91573; E-mail: ms.hejazi@ma.iut.ac.ir

Received March 03, 2015; Accepted Aprile 07, 2015; Published Aprile 13, 2015

Citation: Hejazi MS, Meratian M, Ahmadian M, Fathi MH (2015) Effect of Alumina Amount on the Bioactivity of Dense Magnesium Fluorapatite/Alumina Composite in Simulated Body Fluid (SBF) using Taguchi Method. J Bioprocess Biotech 5: 219 doi: 10.4172/2155-9821.1000219

Copyright: (c) 2015 Hejazi MS, et al. This is an open-access article distributed under the terms of the Creative Commons Attribution License, which permits unrestricted use, distribution, and reproduction in any medium, provided the original author and source are credited. 
Citation: Hejazi MS, Meratian M, Ahmadian M, Fathi MH (2015) Effect of Alumina Amount on the Bioactivity of Dense Magnesium Fluorapatite/ Alumina Composite in Simulated Body Fluid (SBF) using Taguchi Method. J Bioprocess Biotech 5: 219 doi: 10.4172/2155-9821.1000219

Page 2 of 5

In order to approve and confirm the bone-like apatite formation, Fourier Transform Infrared Spectrometer (FTIR), (Burker Tensor), was employed to identify the appearance of $\mathrm{OH}^{-}, \mathrm{PO}_{4}^{3-}$, and $\mathrm{CO}_{3}{ }^{2-}$ in a wavelength range of 600 to $4000 \mathrm{~cm}^{-1}$. The phases of the immersed MFA/alumina samples were determined using X-ray diffraction (Philips diffractometer $(40 \mathrm{kV})$ with a $\mathrm{Cu}_{\mathrm{Ka}}$ radiation of $\left.0.15406 \mathrm{~nm}\right)$. Inductively-Coupled Plasma (ICP), spectrometry (DV7300-Perkin Elmer) was employed to identify the ion concentration changes of the solutions during soaking in SBF. The formation and the growth of bone-like apatite on the soaked pellet surfaces over different immersion times were investigated using a scanning electron microscope (SEM, Phillips XL 30). Fracture toughness $\left(\mathrm{K}_{\mathrm{IC}}\right)$ and hardness (Hv) were determined using the following equations [15]:

\section{$\mathrm{K}_{\mathrm{IC}}=0.0824 \mathrm{P} / \mathrm{C}^{3 / 2}, \mathrm{H}_{\mathrm{v}}=1.854 \mathrm{P} / \mathrm{d}^{2}$}

Where, P stands for applied load (N), C for crack length, $d$ stands for the diagonal length of the indentation.

\section{Results}

\section{Taguchi method}

According to Chen and Wang reports [17], the success of two step sintering strongly depends on the choices of temperatures $\mathrm{T}_{1}$ and $\mathrm{T}_{2}$. In their experiment, a sample is sintered to the higher temperature $\mathrm{T}_{1}$ to achieve a density higher than $75 \%$, corresponding to a state in which all pores in the sample are unstable and shrinkable. It is reported that the MFA relative density was reached to $94 \%$ at $1050^{\circ} \mathrm{C}$ for $1 \mathrm{~min}$ by Hidouri et al. [20]. Therefore, TSS process as below: $T_{1}=1050, t_{1}=1 \mathrm{~min}$, $\mathrm{T}_{2}=950$ and $\mathrm{t}_{2}=20 \mathrm{~h}$ was applied for MFA only. TSS $\mathrm{p}_{2}$ processes were designed for composite samples followed by Taguchi method. To determine the initial temperature, conventional sintering for MFA composite with $50 \%$ alumina was performed at different temperatures from 1000 to $1300^{\circ} \mathrm{C}$. The densities of composite samples are shown in Table 1 . The temperature resulting in $75 \%$ of relative density and higher densities are suitable for the selection of the initial temperatures [15]. Figure 1a shows MFA composite sample with $50 \%$ alumina sintered at temperature of $1250^{\circ} \mathrm{C}$. Alumina, MFA, $\beta$-TCP and calcium aluminate phases were observed. The higher sintering initial temperature as well as the higher alumina content in MFA $/ 50 \%$ alumina composite is illustrating further decomposition of MFA into $\beta$-TCP and the $\mathrm{CaAl}_{2} \mathrm{O}_{4}$ formation. Figure $1 \mathrm{~b}$ shows XRD pattern of MFA/ $50 \%$ alumina sintered at $1300^{\circ} \mathrm{C}$. While temperature of $1300^{\circ} \mathrm{C}$ is resulting $79.5 \%$ of relative density (Table 1), MFA entirely decomposed into $\beta$-TCP (Figure 1 ). Because of this, temperatures of $1300^{\circ} \mathrm{C}$ or higher wasn't suitable for initial temperature. Table 2 presents the design of experiments by Taguchi method and the values of densities corresponding to each experiment. Three levels for each variable refer to the maximum and minimum limits that influence on the density of the final products.

The influential parameters which obtained from ANOVA analysis are listed in Tables 3, 4 and 5 for MFA composite samples with 10, 25 and 50\% a-alumina, respectively. The most influential parameters are the initial temperature $\left(\mathrm{T}_{1}=68.809 \%\right)$ and secondary temperature $\left(\mathrm{T}_{2}=21.090\right)$, the initial temperature $\left(\mathrm{T}_{1}=26.745 \%\right)$ followed by dwell

\begin{tabular}{|c|c|}
\hline Sintering temperature $\left({ }^{\circ} \mathbf{C}\right)$ & Density $(\%$ TD) \\
\hline 1000 & 69.0 \\
\hline 1100 & 71.5 \\
\hline 1200 & 75.0 \\
\hline 1300 & 79.5 \\
\hline
\end{tabular}

Table 1: Relative density and crystallite size for MFA composite with $50 \%$ alumina.

\begin{tabular}{|c|c|c|c|c|c|c|}
\hline Exp. No & $\mathbf{T}_{\mathbf{1}}\left({ }^{\circ} \mathbf{C}\right)$ & $\mathbf{T}_{\mathbf{2}}\left({ }^{\circ} \mathbf{C}\right)$ & $\mathbf{t}_{\mathbf{2}}(\mathbf{h})$ & $\begin{array}{c}\mathbf{1 0 \%} \\
\text { alumina }\end{array}$ & $\begin{array}{c}\mathbf{2 5 \%} \\
\text { alumina }\end{array}$ & $\begin{array}{c}\mathbf{5 0 \%} \\
\text { alumina }\end{array}$ \\
\hline 1 & 1150 & 1000 & 4 & 81.19 & 80.30 & 74.39 \\
\hline 2 & 1150 & 1050 & 8 & 82.51 & 80.35 & 74.83 \\
\hline 3 & 1150 & 1100 & 12 & 83.03 & 83.16 & 74.11 \\
\hline 5 & 1200 & 1000 & 8 & 83.43 & 82.76 & 75.31 \\
\hline 6 & 1200 & 1050 & 12 & 84.28 & 84.32 & 75.74 \\
\hline 7 & 1200 & 1100 & 4 & 86.09 & 83.00 & 74.75 \\
\hline 8 & 1250 & 1100 & 12 & 79.94 & 82.62 & 75.63 \\
\hline 9 & 1250 & 1050 & 4 & 79.61 & 80.65 & 75.56 \\
\hline
\end{tabular}

Table 2: Design of experiments by Taguchi method accompany with the values of composites density corresponding to each experiment.

time $\left(t_{2}=25.329\right)$ and secondary temperature $\left(\mathrm{T}_{2}=18.943\right)$, the initial temperature $\left(\mathrm{T}_{1}=62.669 \%\right)$ and dwell time $\left(\mathrm{t}_{2}=2.662\right)$, respectively. The highest influence on their relative density is related to $T_{1}$ because of its exponential form [21]. In addition to, alumina sintering is carried out in the high enough temperatures (range between 1400 to $1750^{\circ} \mathrm{C}$ ) [22]. So, the sintering optimum conditions (TSS ${ }_{2}$ process) as well as higher densification was obtained at higher initial temperature. Furthermore, at high temperature, grain boundary diffusion is active in removing pores, giving more densification [21]. A combination of $\left[\left(\mathrm{T}_{1}\right)_{2},\left(\mathrm{~T}_{2}\right)_{3}\right.$, $\left.\left(\mathrm{t}_{2}\right)_{2}\right],\left[\left(\mathrm{T}_{1}\right)_{2},\left(\mathrm{~T}_{2}\right)_{3},\left(\mathrm{t}_{2}\right)_{3}\right]$ and $\left[\left(\mathrm{T}_{1}\right)_{3},\left(\mathrm{~T}_{2}\right)_{2},\left(\mathrm{t}_{2}\right)_{2}\right]$ as the highest yield for MFA composite samples with 10, 25 and $50 \%$ alumina, respectively.

\section{SBF behavior using TSS process.}

Figures $2 \mathrm{a}-2 \mathrm{~d}$ shows the FTIR observations of the composite samples after immersion in SBF for 28 days. The presence of wide bands in the range of $1000-1150 \mathrm{~cm}^{-1}$ is reportedly attributed to $\mathrm{PO}_{4}$ vibrations. The absorption peaks located at 720, 1410-1490, and 15201560 were assigned to the $\mathrm{CO}_{3}$ bands [23]. The band at $1670 \mathrm{~cm}^{-1}$ was attributed to $\mathrm{H}_{2} \mathrm{O}$ bands and the characteristic peak at $3575 \mathrm{~cm}^{-1}$ was derived from the $\mathrm{OH}$ band [9]. The FTIR bands confirmed the development of phosphate and carbonate bands and, subsequently, the formation of the apatite layer on the composite surfaces by immersion in SBF for 28 days.

Figures 3a-3d shows XRD patterns for MFA/alumina composites after immersion in SBF for 28 days. The XRD patterns confirm the results obtained from FTIR analysis. The diffractions from the sample surfaces after the 28th day immersion in SBF show the presence of $\beta$-TCP and the formation of apatite on sample surfaces. The broadening of $\beta$-TCP and apatite peaks occurred due to alumina addition (Figure 4) since it indicates the formation of a non-crystallite phase on the sample surfaces. Furthermore, the decreasing $\beta$-TCP intensity with increasing alumina content indicates the excessive decomposition of SBF due to the dissociation of magnesium fluorapatite. The higher $\beta$-TCP solubility results in higher bioactivity and accelerates the growth rate of bone-like HA. It may be concluded that appetites associated with $\beta$-TCP exhibit a good biological response in SBF $[6,10]$. The changes in $\mathrm{Ca}$ and $\mathrm{P}$ ion concentrations in response to different immersion times are shown in Figures $5 a-5 c$. The formation and growth of apatite corresponding to the dynamic process follow as the material surfaces dissolve and the apatite layers precipitate on the surface. The formation of apatite in SBF is expressed as follows [13]:

$10 \mathrm{Ca}^{2+}+(6-\mathrm{X}) \mathrm{PO}_{4}^{3-}+2 \mathrm{OH}^{-}+\mathrm{xCO}_{3}^{2-} \rightarrow \mathrm{Ca}_{10}\left(\mathrm{PO}_{4}\right)_{6-\mathrm{x}}\left(\mathrm{CO}_{3}\right)_{\mathrm{x}}(\mathrm{OH})_{2}(1)$

Therefore, $\mathrm{Ca}$ ion concentration increases with the dissolution of the surface layer. Thus, it is believed that apatite nucleation and growth occur with $\mathrm{Ca}$ and $\mathrm{P}$ ion consumption. As seen during the test 


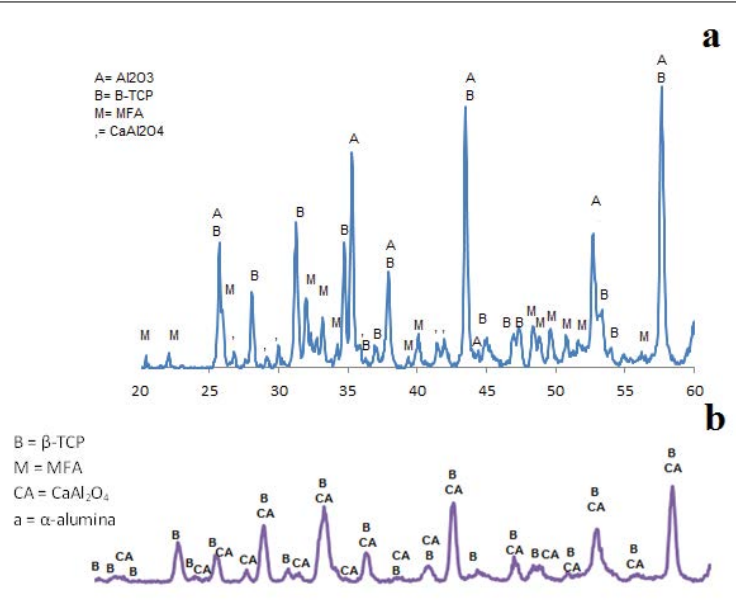

Figure 1: XRD pattern of MFA $/ 50 \%$ alumina sintered at a) $1250^{\circ} \mathrm{C}$ and b) $1300^{\circ} \mathrm{C}$.

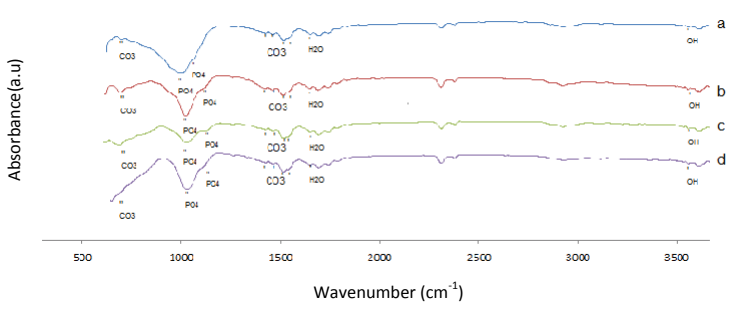

Figure 2: FTIR spectra of a) pure MFA, b) MFA $/ 10 \%$ alumina, c) MFA/25\% alumina and d) MFA $/ 50 \%$ alumina after immersion in SBF for 28 days.

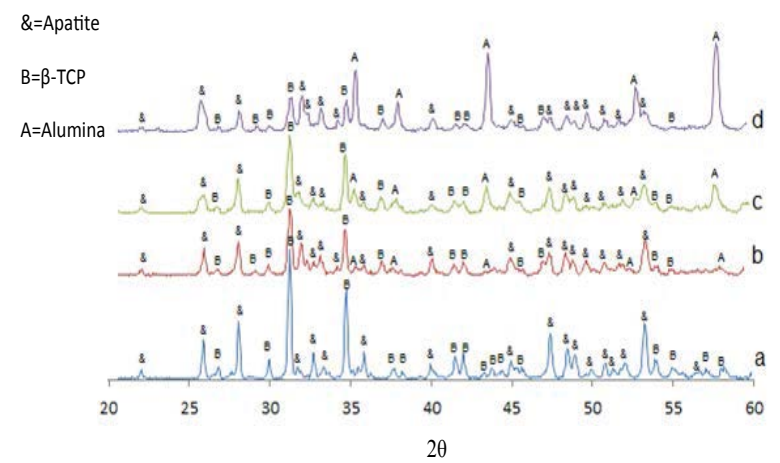

Figure 3: XRD patterns for a) MFA, b) MFA/10\% alumina, c) MFA/25\% alumina and d) MFA $/ 50 \%$ alumina after immersion in SBF 28 days.

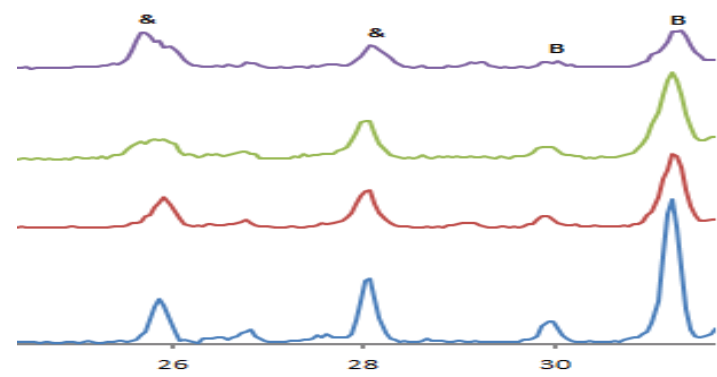

Figure 4: The Broadening of the $\beta$-TCP and apatite peaks.
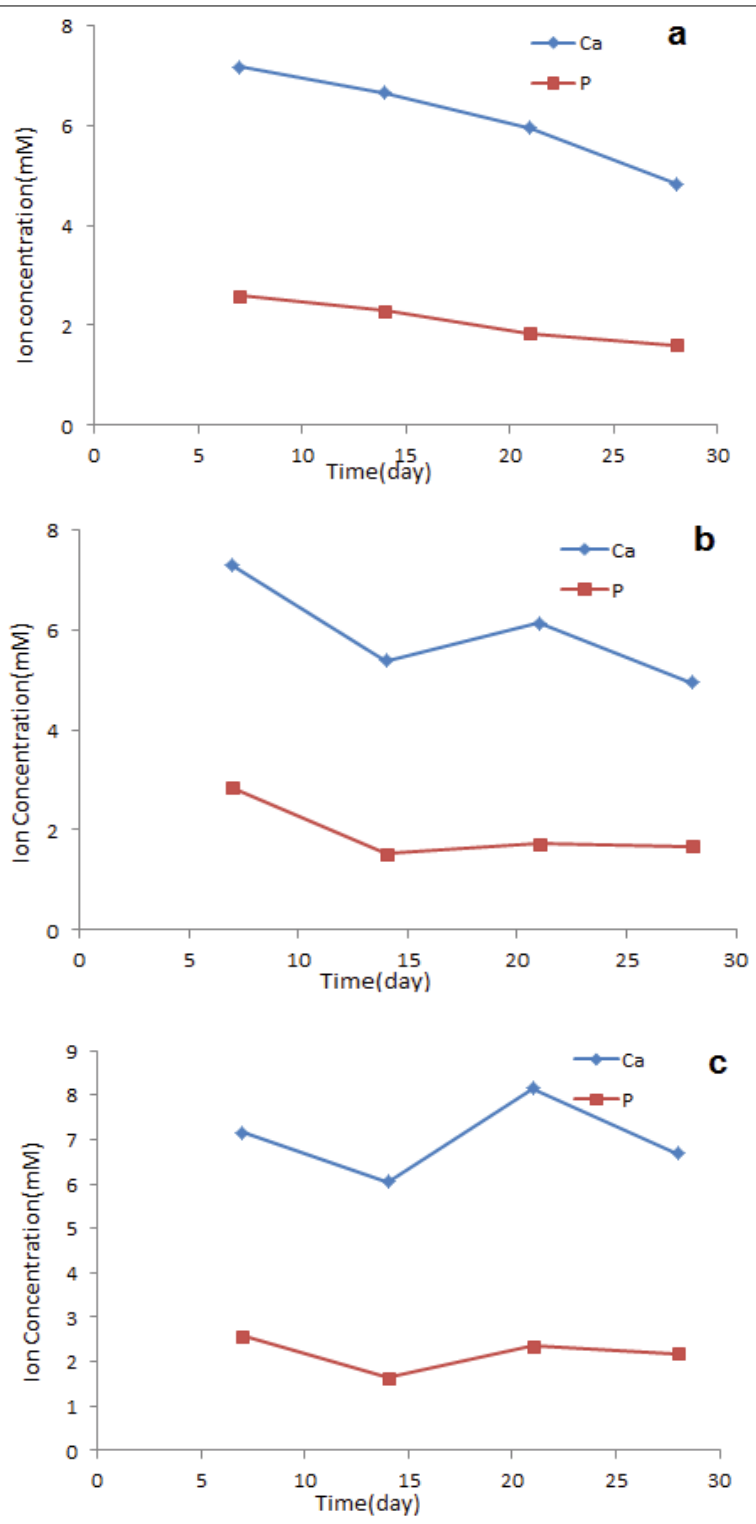

Figure 5: $\mathrm{Ca}$ and $\mathrm{P}$ ion concentrations changes with immersion time for a) MFA, b) MFA $25 \%$ alumina, and c) MFA/50\% alumina in SBF.

\begin{tabular}{|c|c|c|c|c|c|c|}
\hline Parameters & $\begin{array}{c}\text { Sum of } \\
\text { squares }\end{array}$ & $\begin{array}{c}\text { Degrees of } \\
\text { freedom }\end{array}$ & variance & $\begin{array}{c}\text { Pure sum } \\
\text { of squares }\end{array}$ & F-ratio & influence \\
\hline $\mathrm{T}_{1}$ & 24.371 & 2 & 12.185 & 23.35 & 23.299 & 68.809 \\
\hline $\mathrm{T}_{2}$ & 8.195 & 2 & 4.097 & 7.149 & 7.834 & 21.090 \\
\hline $\mathrm{t}_{2}$ & 0.285 & 2 & 0.142 & --- & 0.273 & 0 \\
\hline Error/other. & 1.045 & 2 & 0.522 & --- & --- & 10.101 \\
\hline Total & 33.898 & 8 & --- & --- & --- & 100 \\
\hline
\end{tabular}

Table 3: ANOVA of the influential parameters for the MFA/10 \% alumina.

\begin{tabular}{|c|c|c|c|c|c|c|}
\hline Parameters & $\begin{array}{c}\text { Sum of } \\
\text { squares }\end{array}$ & $\begin{array}{c}\text { Degrees of } \\
\text { freedom }\end{array}$ & Variance & $\begin{array}{c}\text { Pure sum } \\
\text { of squares }\end{array}$ & F-ratio & influence \\
\hline $\mathrm{T}_{1}$ & 6.560 & 2 & 3.295 & 5.185 & 4.691 & 26.745 \\
\hline $\mathrm{T}_{2}$ & 5.077 & 2 & 2.538 & 3.672 & 3.614 & 18.943 \\
\hline $\mathrm{t}_{2}$ & 6.315 & 2 & 3.157 & 4.911 & 4.495 & 25.329 \\
\hline Error/other. & 1.403 & 2 & 0.701 & --- & --- & 28.893 \\
\hline Total & 19.388 & 8 & --- & --- & --- & 100 \\
\hline
\end{tabular}

Table 4: ANOVA of the influential parameters for the MFA/25\% alumina. 
Citation: Hejazi MS, Meratian M, Ahmadian M, Fathi MH (2015) Effect of Alumina Amount on the Bioactivity of Dense Magnesium Fluorapatite/ Alumina Composite in Simulated Body Fluid (SBF) using Taguchi Method. J Bioprocess Biotech 5: 219 doi: 10.4172/2155-9821.1000219

Page 4 of 5

\begin{tabular}{|c|c|c|c|c|c|c|}
\hline Parameters & $\begin{array}{c}\text { Sum of } \\
\text { squares }\end{array}$ & $\begin{array}{c}\text { Degrees of } \\
\text { freedom }\end{array}$ & Variance & $\begin{array}{c}\text { Pure sum } \\
\text { of squares }\end{array}$ & F-ratio & influence \\
\hline $\mathrm{T}_{1}$ & 2.933 & 2 & 1.466 & 2.526 & 7.200 & 62.669 \\
\hline $\mathrm{T}_{2}$ & 0.175 & 2 & 0.087 & --- & 0.430 & 0 \\
\hline $\mathrm{t}_{2}$ & 0.514 & 2 & 0.257 & 0.107 & 1.263 & 2.662 \\
\hline Error/other. & 0.406 & 2 & 0.203 & --- & --- & 34.669 \\
\hline Total & 4.030 & 8 & --- & --- & --- & 100 \\
\hline
\end{tabular}

Table 5: ANOVA of the influential parameters for the MFA/50\% alumina.

\begin{tabular}{|c|c|c|c|}
\hline $\begin{array}{c}\text { Composite } \\
\text { Samples }\end{array}$ & Sintering method & Hardness(GPa) & $\begin{array}{c}\text { Toughness(Mpa. } \\
\mathbf{m}^{\wedge} \mathbf{( 1 / 2 ) )}\end{array}$ \\
\hline $\mathrm{MFA}$ & $\mathrm{TSS}_{1}$ & $6.38 \pm 1.29$ & $2.2 \pm 0.82$ \\
\hline $\mathrm{MFA} / 10 \% \mathrm{Al}_{2} \mathrm{O}_{3}$ & $\mathrm{TSS}_{2}$ & $12.39 \pm 0.86$ & $1.97 \pm 0.98$ \\
\hline $\mathrm{MFA} / 25 \% \mathrm{Al}_{2} \mathrm{O}_{3}$ & $\mathrm{TSS}_{2}$ & $16.62 \pm 6.4$ & $3.87 \pm 1.38$ \\
\hline $\mathrm{MFA} / 50 \% \mathrm{Al}_{2} \mathrm{O}_{3}$ & $\mathrm{TSS}_{2}$ & $22.09 \pm 3.5$ & $5.82 \pm 1.05$ \\
\hline
\end{tabular}

Table 6: Mechanical properties of $M F A / \mathrm{Al}_{2} \mathrm{O}_{3}$ composites sintered via TSS

days of SBF immersion (Figure 5a), the continuous reduction in $\mathrm{Ca}$ and $\mathrm{P}$ ion concentrations are associated with apatite nucleation and growth. Reportedly, fluctuations of $\mathrm{Ca}$ and $\mathrm{P}$ concentrations in SBF with immersion time (Figures $5 \mathrm{~b}$ and $5 \mathrm{c}$ ) are due to reduced apatite formation (corresponding to decreasing $\mathrm{Ca}$ and $\mathrm{P}$ ion concentrations) and higher dissolution of $\beta$-TCP (corresponding to increasing $\mathrm{Ca}$ and $\mathrm{P}$ ion concentrations). Furthermore, the accelerated phase dissociation is confirmed by the decrease in $\beta$-TCP intensity shown in the XRD patterns. The $\beta$-TCP dissolution after soaking HA in SBF is expressed as follows [1]:

$$
4 \mathrm{Ca}_{3}\left(\mathrm{PO}_{4}\right)_{2}+\mathrm{H}_{2} \mathrm{O} \rightarrow \mathrm{Ca}_{10}\left(\mathrm{PO}_{4}\right)_{6}(\mathrm{OH})_{2}+2 \mathrm{Ca}^{2+}+2 \mathrm{HPO}_{4}^{2-}
$$

Bioactivity of magnesium fluorapatite is basically affected by the amount of dissolved $\beta$-TCP in Simulated Body Fluid (SBF).

The Mg ion concentration changes with different immersion times, as shown in Figures 6a-6c. The presence of $\mathrm{Mg}$ ions in SBF is due to the MFA matrix and $\beta$-TCP dissolution. It is also clear from Figure 6 that $\mathrm{Mg}$ ion concentration decreases with time, which could be due to the substitution of $\mathrm{Mg}$ ions from the SBF solution for $\mathrm{Ca}$ ions in calcium phosphates obtained from SBF. It has also been reported that $\mathrm{Mg}$ is the key factor in the formation of calcium phosphates from SBF which inhibit its precipitation in the solution [24]. It is observed that $\mathrm{Mg}$ ion concentration undergoes less change in the MFA/alumina composites than in pure MFA, indicating the role of alumina in preventing increased $\mathrm{Mg}$ content in the SBF solution.

The higher apatite on the MFA/alumina composite surfaces is due to higher bioactivity in comparison to MFA only (Figures 7 and 8). Spherical apatite particles formed on the surface is because of the surface tension and adhesion force co-effect around the crystals [13]. Covering the whole surface with spherical apatite particles is observed in composite samples with 10 and $25 \%$ alumina after 7 days of immersion in SBF (Figures 7a-7c). Moreover, there are a few spherical particles in MFA/50\% alumina which are either dispersed or accumulated (Figure $7 \mathrm{~d}$ ). The accelerated nucleation and the formation of accumulated spherical particles on the surface are detected after 21 days of immersion in SBF (Figures 8a-8d). A relatively bulk apatite formed on MFA $10 \%$ alumina might be due to the accelerated apatite growth during the 21-day immersion in SBF.

\section{Mechanical properties}

It can be seen that fracture toughness and hardness of $\mathrm{MFA} / \mathrm{Al}_{2} \mathrm{O}_{3}$ composite increased with increasing alumina. Furthermore, addition of a harder phase as alumina to MFA increased hardness. Increasing

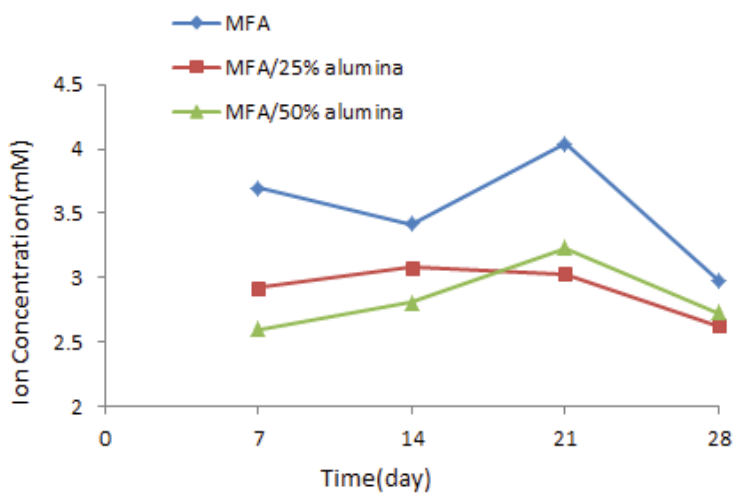

Figure 6: Changes in Mg ion concentration with immersion time for a) MFA, b) MFA $25 \%$ alumina and C) MFA $/ 50 \%$ alumina in SBF.
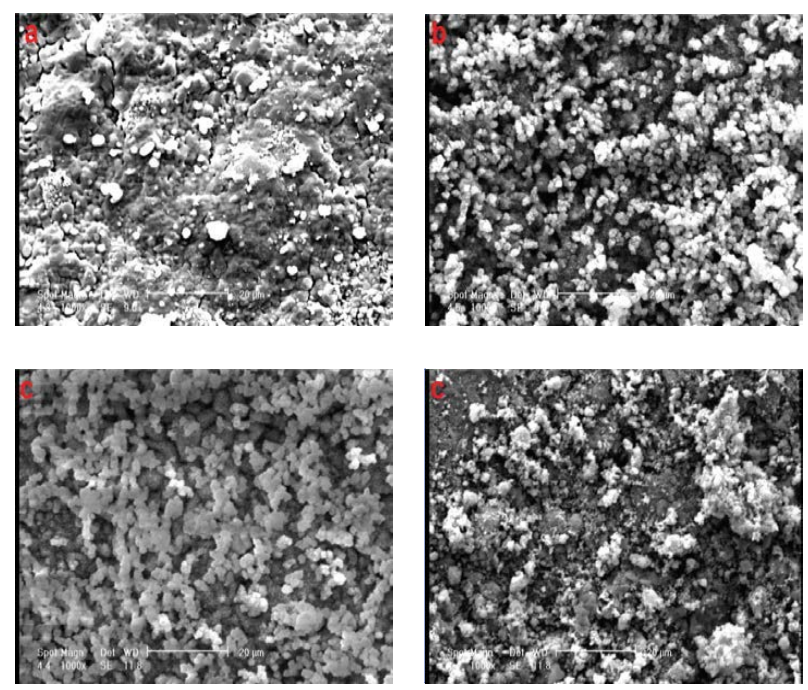

Figure 7: Apatite appearance with different morphologies for the samples a) pure MFA, b) MFA $/ 10 \%$ alumina, c) MFA/25\% alumina and d) MFA/50\% alumina after 7 days immersion in SBF.
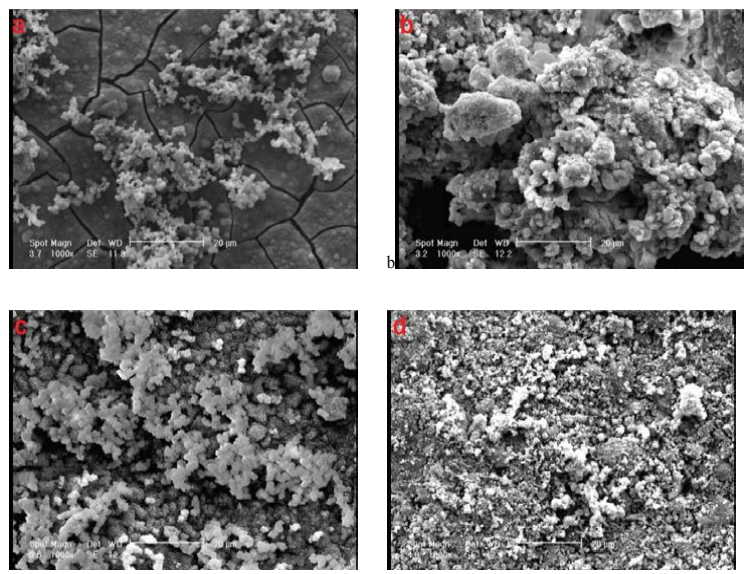

Figure 8: Surface morphologies of a) purity MFA, b) MFA $10 \%$ alumina, c) MFA $/ 25 \%$ alumina and d) MFA $/ 50 \%$ alumina after 21 days immersion in SBF. 
Citation: Hejazi MS, Meratian M, Ahmadian M, Fathi MH (2015) Effect of Alumina Amount on the Bioactivity of Dense Magnesium Fluorapatite/ Alumina Composite in Simulated Body Fluid (SBF) using Taguchi Method. J Bioprocess Biotech 5: 219 doi: 10.4172/2155-9821.1000219

Page 5 of 5

in fracture toughness is due to prevention of crack growth by alumina.

\section{Discussion}

The FTIR bands and the X-ray patterns confirmed the formation of an apatite layer on the sample surfaces after 28 days of soaking in $\mathrm{SBF}$. The continuous decrease in $\mathrm{Ca}$ and $\mathrm{P}$ ion concentrations indicated the nucleation and growth of apatite for MFA from 7 to 28 days of immersion in SBF. Increasing alumina content led to higher $\beta$-TCP dissolution and prevented $\mathrm{Mg}$ addition in the SBF solution. In all the composite samples, apatite from SBF solution was formed with the $\beta$-TCP phase. Dissolution of $\beta$-TCP increases with alumina addition. The mechanical properties (fracture toughness and hardness) of magnesium/fluorapatite were increased with alumina addition.

\section{Acknowledgments}

The authors are grateful to Isfahan University of Technology for supporting the present research.

\section{References}

1. Gu YW, Khor KA, Cheang $P$ (2004) Bone-like apatite layer formation on hydroxyapatite prepared by spark plasma sintering (SPS). Biomaterials 25 4127-4134.

2. Ashuri M, Moztarzadeh F, Nezafati N, Hamedani AA, Tahriri M (2012) Development of a composite based on hydroxyapatite and magnesium and zinc-containing sol-gel-derived bioactive glass for bone substitute applications. Materials Science and Engineering: C 32: 2330-2339.

3. Singh VK, Ravindra Reddy B (2012) Synthesis and characterization of bioactive zirconia toughened alumina doped with HAp and fluoride compounds. Ceramics International 38: 5333-5340.

4. Evis Z, Doremus RH (2007) A study of phase stability and mechanical properties of hydroxylapatite-nanosize a-alumina composites. Materials Science and Engineering: C 27: 421-425.

5. Hejazi MS, Ahmadian M, Meratian M, Fathi MH (2014) Effect of alumina contents on phase stability and mechanical properties of magnesium fluorapatite/alumina composites. J Mech Behav Biomed Mater 40: 95-101.

6. Nakahira A, Tamai M, Aritani H, Nakamura S, Yamashita K (2002) Biocompatibility of dense hydroxyapatite prepared using an SPS process. J Biomed Mater Res 62: 550-557.

7. Bohner M, Lemaitre $J(2009)$ Can bioactivity be tested in vitro with SBF solution? Biomaterials 30: 2175-2179.

8. Kim HM, Himeno T, Kawashita M, Kokubo T, Nakamura T (2004) The mechanism of biomineralization of bone-like apatite on synthetic hydroxyapatite: an in vitro assessment. J R Soc Interface 1: 17-22.

9. Pierri J, Roslindo EB, Eliria RT, Agnolon Pallone MJ, Rigo E (2006) Alumina/ zirconia composite coated by biomimetic method. Journal of Non-Crystalline
Solids 352: 5279-5283.

10. Qi G, Zhang S, Khor KA, Liu C, Zeng X, et al. (2008) In vitro effect of magnesium inclusion in sol-gel derived apatite. Thin Solid Films 516: 5176-5180.

11. Zhang M, Liu C, Zhang X, Pan S, Xu Y (2010) $\mathrm{Al}_{2} \mathrm{O}_{3}$ /diopside ceramic composites and their behaviour in simulated body fluid. Ceramics International 36: 2505-2509.

12. Priya A, Nath S, Biswas K, Basu B (2010) In vitro dissolution of calcium phosphate-mullite composite in simulated body fluid. J Mater Sci Mater Med 21: $1817-1828$.

13. Xin F, Jian C, Peng ZJ, Qian W, Cheng ZZ, et al. (2009) Bone-like apatite formation on HA/316L stainless steel composite surface in simulated body fluid. Trans Nonferrous Metal Society China 19: 347-352.

14. Baek SH, Hong SH, Cho SS, Jang DY, Joo WS (2010) Optimization of process parameters for recycling of mill scale using Taguchi experimenal design. Journal of Mechanical Science and Technology 24: 2127-2134.

15. Lourenc MA, Cunto GG, Figueiredo FM, Frade JR (2011) Model of two-step sintering conditions for yttria-substituted zirconia powders. Materials Chemistry and Physics 126: 262-271.

16. Aminzare M, Golestani-fard F, Guillon O, Mazaheri M, Rezaie HR (2010) Sintering behavior of an ultrafine alumina powder shaped by pressure filtration and dry pressing. Materials Science and Engineering A 527: 3807-3812.

17. Wang CJ, Huang CY, Wu YC (2008) Two-step sintering of fine alumina-zirconia ceramics. Ceramics International 35: 1467-1472.

18. Lin K, Chen L, Chang J (2012) Fabrication of dense hydroxyapatite nanobioceramics with enhanced mechanical properties via two-step sintering process. International Journal of Applied Ceramic Technology 9: 479-485.

19. Berginc B, Kampus Z, Sustarsic B (2006) The use of the Taguchi approach to determine the influence of injection-moulding parameters on the properties of green parts. Journal of Achievements in Materials and Manufacturing Engineering 15: 63-70.

20. Hidouri M, Bouzouita K, Kooli F, Khattech I (2003) Thermal behaviour of magnesium-containing fluorapatite. Materials Chemistry and Physics 80: 496505.

21. Arockiasamy A, German RM, Wang P, Horstemeyer MF, Morgan W, et al (2010) Sintering behaviour of Al-6061 powder produced by rapid solidification process. Powder Metallurgy. The Charlesworth Group.

22. Guidara A, Chaari K, Bouaziz J (2011) Elaboration and characterization of alumina-fluorapatite composites. JBNB 2: 103-113.

23. Obata A, Hasegawa D, Nakamura J, Jones JR, Kasuga T (2012) Induction of hydroxycarbonate apatite formation on polyethylene or alumina substrates by spherical vaterite particles deposition. Materials Science and Engineering $C$ 32: 1976-1981.

24. Barrere F, Blitterswijk CA, Groot K, Layrolle $P$ (2002) Nucleation of biomimetic Ca-P coatings on Ti6Al4V from a SBF $\times 5$ solution: influence of magnesium. Biomaterials 23: 2211-2220. 